\title{
Analisis Politik dan Hukum Pemilihan Presiden Secara Langsung.
}

\author{
Zulfirman
}

\begin{abstract}
$\therefore, \quad \because \quad, \quad: \quad$,
\section{Abstract}

The idea the President election directly by the people is not validated because it contradicts with the basic political principles (ideal principles, Pancasila) and formal juridical principle as expressed on Paragraph 1 aiticle (2) Constitution 1945. In the frame of strengthen for law supremacy it will bee any clash between the political will and the law desires about President election directly by the People:
\end{abstract}

\section{Pendahuluan}

Tanggal 17 Agustus $1945^{\prime}$ adalah merupakan hari yang sangat penting bagi bangsa Indonesia baik dari segi sosial, ekơnomi, hukum, politik, ketatanegaraan dan se-gala aspek lain dari kehidupan suatu bangsa. Pada hari itu, telah diproklamirkan kemerdekaan bangsa Indonesia sebagai tanda bangsa Indonesia telah terlepas dari penjajahan bangsa lain. Dari optik hukum, hari tersebut tersebut adalah merupakan sumber tata hukum Indonesia sebagai suatu negara yang merdeka dan berdaulat.

Syarat negara modern, suatu negara merdeka dan berdaulat yang harus memiliki dasar idiil dan dasar konstitusionil sebagai dasar menyelenggarakan negara atau pemerintahan; , dalam . memenuhi persyarataan tersebut, satu hari setelah proklamasi tersebut disahkannya UUD 1945 pada tanggal 18 Agustus 1945 pada saät yang bersamaan pula ditetapkanlah Presiden dan Wakil. Presiden Indonesia negara Indonesia yang baru merdeka waktu itu, yaitu Ir.Soekarno sebagai Presiden dan Moh. Hatta sebagai wakil Presiden.

Sejak detik proklamasi tanggal 17 Agustus 1945 sekitar pukul 8.00 Wib pagi hingga disahkannya UUD 1945 dan ditetapkannya Présiden dan Wakil Presiden tanggal 18 Agustus $1945^{\circ}$ kekuasaan negara, secara materiel dan formil, murni berada di tangan selurüh rakyat Indonesia. ${ }^{1}$ Sejak tanggal 18

'Perhatikan teks proklamasi kemerdekaan Indonesia, bahwa Soekarno dan Mohd. Hatta bertindak atas nama bangsa Indonesia. 
Agustus .1945, Soekarno menjadi Presiden Republik Indonesia yang pertama, dan dalam penyelenggaraan negara Indonesia Presiden mengacu kepada ketentuan yang termuat di dalam UUD 1945, walau pun pada prakteknya, dalam waktu kurang dari tiga bulan setelah proklamasi kemerdekaan, ketika dibentuk Kabinet Parlementer Pertama di bawah Perdana Menteri Syahrir, UUD 1945 yang menganut sistem presidential (quasi) itu sudah tidak lagi dijadikan pegangan dalam praktek penyelenggaraan negara. Keadaan ini terus berlangsung sampai terbentuknya Republik Indonesia Serikat sebagai hasil perundingan Konperensi Meja Bundar yang memberlakukan Konstitusi RIS tahun 1949.2

UUD 1945 yang disahkan dan berlaku pada tanggal 18 Agustus 1945 adalah konstitusi Negara Indonesia yang sifatnya sementara, demikian juga Konstitusi RIS 1949 hasil kesepakatan dengan Belanda sebagaimana ketentuan Pasal 186 Konstitusi RIS yang mengamanatkan, bahwa UUD yang tetap akan disusun oleh Konstituante. Amanat Pasal 186 Konstitusi RIS ini dilanjutkan lagi oleh Pasal 134 UUDS 1950 setelah negara Indo-nesia kembali menjadi Negara Kesatuan Republik indonesia (NKRI) pada tanggal 17 Agustus 1950.

Namun, pada prakteknya Konstituante yang dibentuk pada tanggal 10 November
1956 dengan membuat konstitusi itu tidak berhasil membentuk. Konstitusi Negara indonesia yang sifatnya tetap. ${ }^{3}$ Karena pada tanggal. 5 Juli 1959, Presiden Soekarno menge-luarkan dekrit yang isinya membubarkan Konstituante dan memberlakukan kembali UUD 1945 dengan alasan adanya keadaan darurat. Sejak saat itu, 5 juli 1959, maka UUD 1945 berlaku sebagai konstitusi R.I hingga saat ini.

UUD 1945 merupakan acuan dan atau pedoman dalam penyelenggaraan Negara RI isinya sangat singkat dan "soeper". Karena sifatnya sangat "soepel" tersebut UUD 1945. cenderung disalahgunakan dengan penafsiran-penafsiran oleh pihak yang berkuasa seca-ra sepihak. ${ }^{4}$ Penafsiran oleh. pihak yang berkuasa, Presiden, selalu dilakukan untuk ke-pentingan dan berpihak kepada kepentingan dan keuntungan penguasa, Presiden, akibat-nya muncul subur otoritarianisme berlindung di belakang kata demokrasi dan konstitusi. Semua itu, berdampak berkembangnya praktek-praktek korupsi, kolusi, dan nepotisme di sekitar penguasa, Presiden, dan yang paling dirugikan rakyat dan negara.

Penyalahgunaan UUD 1945 demi kepentingan penguasa dapat terlihat dari apa yang dilakukan Presiden Soekarno pada masa orde lama dan Presiden Soeharto pada masa orde baru, di mana kekuasaan negara berada

${ }^{2}$ Jimly Asshiddiqie. "Undang-Undang Dasar Negara Kesatuan Republik Indonesia, Pengantar Perubahan." Makalaht.t. HIm.1.

${ }^{3}$ Lihat pendapat J.C.T:Simorangkir yang mengatakan, bahwa konstituante Bandung tidak berhasil menyusun UUD yang tetap bagi negara Indonesia, sedangkan dalam bidang materi konstitusi, konstituante cukup banyak hasil karyanya sebagaimana dikutip Moh. Mahfud MD. 2001. Politik Hukum di Indonesia. Jakarta: LP3ES. HIm. 134.

${ }^{4}$ Jimly Asshidiqie. Op. Cit. HIm. 2. 
pada penguasa. Akibat munculnya otoritarianisme di tangan presiden dan terjadi penumpulan kekuasaan negara lainnya di bidang legislatif dan yudikatif.

Penafsiran UUD 1945, khususnya pasalpasal yang berkenaan dengan lembaga kepresidenan, ${ }^{5}$ yang dilakukan penguasa sesuai dengan kepentingan penguasa dan mempertahankan kedudukan dengan dasar argumentasi- demokrasi. Dalam hal ini arti demokrasi itu sendiri ditafsirkan oleh penguasa, Presiden, secara sepihak sesuai dengan kehendak dan kepentingan penguasa. ${ }^{6}$ Tatanan kehidupan berbangsanegara, sebagai bangsa merdeka modern, dilakukan -secara amat individual, tetapi dengan kemasan konstitusi: Pengatasnamaan konstitusi ini' bahikan :menjadi alat legitimasi yang justru' melahirkan penataan berbangsanegara yang justru dilàkukan dengan perilakuperilaku yang anti konstitusi. ${ }^{7}$ Salah satu upaya untuk mencegah hal tersebut dalam Sidang Istimewa MPR 1998 telah diterbitkan
Ketetapan MPR No. XIII/MPR/1998 yang mengadakan Pembatasan Masa Jabatan Presiden dan Wakil Presiden Republik Indonesia, dan upaya ini dilanjutkan dengan melakukan amandeman atas UUD 1945.

Beranjak dari masalah yang berkenaan dengan lembaga kepresidenan itulah muncul gerakan reformasi yang menyeluruh di Indonesia pada tahun 1998. Reformasi politik dan ekonomi yang bersifat menyeluruh tidak mungkin dilakukan tanpa diiringi oleh reformasi hukum. Tetapi reformasi hukum yang menyeluruh juga tidak mungkin dilakukan tanpa didasari agenda reformasi ketatanegaraan yang mendasar, dan itu berarti diperlukan adanya "constitutional reform" yang tidak setengah hati. ${ }^{8}$ Untuk itulah, berdasarkan pengalaman pahit tersebut, pada masa era reformasi ini disepakati dilakukan amandemen UUD 1945 salah satunya agendanya adalah membatasi dominasi kekuasaan eksekutif (Presiden) dalam penyelenggaraan pemerintahan. $^{9}$

5Lihat juga pendapat Ni'matul Huda. 1999. Hukum Tata Negara Kajian Teoritis dan Yuridis Terhadap Konstitusi Indonesia. Yogyakarta: PSH Fakultas Hukum UII. HIm. 145 yang menyatakan sumber masalah kenegaraan selama ini berasal dari ketidak tegasaan UUD 1945 (misalnya masalah jabatan Presiden).

${ }^{6}$ Peluang memberikan arti pada istilah demokrasi sesuai dengan kehendak penguasa semakin besar terjadi karena istilah demokrasi itu sendiri mengandung pengertian yang ambigu. Mahfud MD dalam bukunya Politik Hukum di Indensia mengatakan: "dalam berbagai literatur, banyak ditemui perbedaan antara demokrasi nomatif dan demokrasi empiris yang belum tentu berjalan seining. Apa yang secara normative-konstitusional demokratis belum tentu demokrasi pula dalam kenyataannya" dalam Mohd.Mahfud MD. Op.Cit HIIm. 3.

${ }^{7}$ Anhar Gonggong. 2001. Amandemen Konstitusi, Otonomi Daerah dan Federalisme, Solusi Untuk Masa Depan. Yogyakarta: Media Pressindo. Him. 27.

8 Jimly Asshiddigie. Op.Cit. Him.:2

${ }^{9} \mathrm{G} e m a$ reformasi yang bergaung beberapa waktu yang lalu ternyata telah menggetarkan hampir semua sendi-sendi kehidupan berbangsa dan bernegara. Semenjak itu sampai dewasa ini, diskursus tentang perlunya penyesuaian terhadap tuntutan perubahan dalam dinamika kehidupan politik ketatanegaraan Indonesia menjadi berlangsung dengan marak tanpa henti-hentinya. Baik itu dilakukan oleh para akademisi, politisi, insan pers, maupun LSM. Dari sudut pandang Hukum Tata Netagara fenomena ini tentu saja sangat penting dan positif 
Amandemen atas UUD 1945 telah dilakukan tiga kali dan memasuki amandemen keempat, yang berkenaan dengan posisi MPR dalam hubungannya dengan itu pada pasca perubahan ketiga UUD 1945; pada pemilu tahun 2004 yang akan datang Presiden dan Wakil Presiden dipilih secara langsung oleh rakyat. Apabila amandemen ini berjalan, maka fungsi dan kewenangan MPR memilih Presiden dan wakil Presiden menjadi hilang dalam praktek ketatanegaraan Indonesia di masa mendatang. Perubahan mana di nilai perubahan yang mendasar karena sangat berhubungan erat dengan corak dan sistem demokrasi Indonesia. Artinya pemilihan Presiden dan Wakil Presiden secara langsung oleh rakyat bersentuhan erat dengan makna dan corak demokrasi yang berdasarkan nilainilai bangsa Indonesia yang telah ada saat ini.

Pasca amandemen ketiga atas UUD 1945 berakibat MPR bukan lagi merupakan Lembaga Tertinggi Negara dalam sistem ketatanegaraan Indonesia masa mendatang yang membawa konsekwensi MPR tidak lagi memilih Presiden sebagai penyelenggara negara tetapi Presiden dan wakilnya dipilih langsung oleh rakyat.

Masalahnya, apakah pemilihan Presiden dan Wakil Presiden secara langsung oleh Rakyat dapat dibenarkan menurut hukum (substansi hukum, filosofis) dan sistem (demokrasi) yang terdapat pada weltanschauung, philosophische gronslag atau pandang-an hidup bangsa Indonesia sebagai sumber hukum dasar nasional negara R.I.

\section{Pancasila sebagai Sumber Hukum Dasar dan Dasar Politik}

Menjawab permasalahan di atas, patokan yang digunakan adalah nilai dasar yang termaktub di dalam pandangan hidup berbangsa dan bernegara dan norma hukum yang berlaku dalam konstitusi negara indonesia, karena perubahan atau amandemen suatu konstitusi harus tetap memegang norma dasarnya, untuk itu apakah hasil aman-demen ketiga itu telah benar menurut nilai-nilai dasar yang dianut oleh bangsa Indonesia yang tẹlah dijadikan weltanschauung, philosophische gronslag atau pandangan hidup bangsa. Hal ini berkaitan erat dengan konsep demokrasi yang berlaku di Indonesia, dan konsep demokrasi tersebut dipengaruhi pula oleh paham, idealisme bangsa Indonesia.

Kelahiran negara Indonesia lahir bukanlah didasarkan kepada kehendak suatu golongan, atau kehendak pribadi, individu, tetapi sebagai kehendak nurani dan realisasi kesepakatan luhur. seluruh bangsa Indonesia ujud dari Sumpah. Pemuda tahun 1928 sebagai ujud kebangkitan rasa kebangsaan

dalam rangka membentuk atau mendesain demokrasi yang berorientasi pada keadilan, supremasi hukum, civil society, chesks and balance yang menabukan domonasi kekuasaan seperti strong presidensiil, akuntabilitas kekuasaan dan pluralisme atau kemajemukan dalam konteks NKRI. Lihat. Dahlan Thaib. "Menuju Parlemen Bikameral (Studi Konstitusional perubahan Ketiga UUD 1945." Pidato Pengukuhan dalam jabatan Guru Besar Madya dalam Hukum Tata Negara. Disampaikan di depan Sidang Senat Terbuka Universitas Islam Indonesia (UII) Yogyakarta pada tanggal 4 Mei 2002. Hlm. 4-5. 
Indonesia: ${ }^{10}$ Landasan idiilnya negara RI adalah Pancasila dan landasan konstitusionil dalam menyelenggarakan pemerintahan negara adalah UUD 1945, sebagai konstitusi negara, yang disahkan pada tanggal 18 Agustus 1945.

Kemerdekaan suatu bangsa dari optik hukum, mengandung makna dan konsekuensi yang sangat hakiki dan mendasar, yaitu, kerelaan dan keikhlasan untuk menyandang suatu hak dan kewajiban. Hak dan kewajiban suatu bangsa tersebuit berlaku ke dalam (internal) dan ke luar (external). Hak dan kewajiban yang berlaku ke dalam berarti negara itu menentukan nasibnya sendiri dan menjalankannya pemerintahan dengan kekuatan dan kemampuannya sendiri. Sedangkan hak dan kewajiban keluar kewenangan bertindak dan berbuat di dalam lalu lintas internasional antar bangsa-bangsa sebagai bangsa yang kedudukannya sama dan seimbang dengan bangsa-bangsa lainnya yang berdaulat.

Sejarah perjalanan bangsa Indonesia dalam mengisi dan melaksanakan serta mencari format tentang hak dan kewajibannya yang diapilikasikan dalam negara banyak mengalami berbagai gejolak dan pemberontakan pada sekala kedaerahan mau pun berskala nasional, antara lain pemberontakan PKI Mediun, PRRI/ Permesta, DII,TII, peristiwa pemberontakan gerakan G.30.S PKI dan terakhir gerakan reformasi yang bergulir pada bulan Mai 1998.

Pencarian isi dan format dari hak dan kewajiban bangsa Indonesia dilakukan dari waktu-waktu. Perubahan mana dapat terjadi dengan cara revolusi, evalusi, dan dapat pula dilakukan melalui reformasi. Revolusi, evolusi, dan reformasi pada hakikatnya mengandung arti yang sama yakni perubahan, namun perbedaan terletak pada percepatannya. Revolusi dilakukan secara cepat dan radikal, evolusi secara lambat, reformasi secara sedang, tidak terlalu cepat dan tidak pula terlalu lambat. Dalam rangka pencarian format dan isi hak dan kewajiban bangsa Indonesia dewasa ini dilakukan secara reformasi, yakni perubahan dilakukan tidak terlalu cepat dan tidak pula terlalu lambat.

Pilihan melakukan perubahan di segala bidang dalam kehidupan berbangsa dan bernegara melalui reformasi dalam mengisi hak dan kewajiban Indonesia merdeka sungguh pilihan yang tepat dan bijaksana, karena dari segi percepatan, diberi waktu yang cukup untuk lebih cermat, teliti, kritis, seksama dalam memahami masalah-masalah dan mengkaji ulang serta menginventarsisasi nilai-nilai yang hidup dan perlu dipertahankan serta nilai-nilai

${ }^{10}$ Semangat persatuan telah terasa sejak awal persidangan dalam kongres pemuda dalam akhir pidato pembukaan Ketua Sidang Soegondo menyerukan "perangilah pengaruh cerai berai dan majulah terus ke arah Indonesia bersatu yang kita cintai". Keputusan yang bertema satu tanah air, satu bangsa dan satu bahasa adalah suatu putusan yang nyata-nyata menentang politik devide et impera dari Pemerintah.Kolonial. S.Silalahi. 2001. Dasar-dasar Indonesia Merdeka versi Para Pendiri Negara. Jakarta:Gramedia Pusaka Utama. HIm. 19. Takasi Shiraishi mengatakan: Kebangkitan nasional pada dasarnya adalah munculnya politik modern di Hidia Belanda. Dan munculnya politik modern itu, menurutnya, secara potensial sudah merupakan ancaman terhadap rezim kolonial. Takasi Shiraishi. 2001. Menuju Demokrasi Politik Indonesia Dalam Persepektif Sejarah. Baskara T.Wardaya (ed). Jakarta: Gramedia. HIm. 133. 
mana yang telah tidak sesuai dengan tuntutan zaman untuk diperbaiki guna kelangsungan hidup bangsa, negara Indonesia masa kini dan mendatang yang mampu menghadapi tantangan era kejagatan.

Esensi hak dan kewajiban suatu bangsa yang harus diujudkan melalui kegiatan politik, ekonomi, hukum, kebudayaan, sosial, dan kegiatan berbangsa dan bernegara ter-dapat pada weltanschauung, philosophische gronslag atau pandangan hidup bangsa dari bangsa tersebut. Oleh karena itu, weltanschauung, philosophische gronslag atau pandangan hidup bangsa mutlak diperlukan dalam mendirikan dan menjalankan suatu negara. " Weltanschauung, philosophische gronslag atau pandangan hidup bangsa adalah merupakan inti sari (kristalisasi) dari nilai-nilai yang dimiliki bangsa itu, dan diyakini kebenarannya, yang berdasarkan pengalaman sejarah, dan yang telah menimbulkan tekad pada bangsa itu untuk mewujudkannya dalam kehidupan sehari-hari. ${ }^{12}$

Weltanschauung, philosophische gronslag atau pandangan hidup bangsa bagi bangsa Indonesia merdeka adalah Pancasila, dan Pancasila tersebut juga sekaligus merupakan Dasar Negara dalam penyelenggaraan negara yang dijabarkan dalam UUD $1945 .{ }^{13}$

Pejjalanan sejarah ketatanegaraan Indonesia Pancasila ini tetap dijadikan weltanschauung, philosophische gronslag atau pandangan hidup bangsa Indonesia dan dasar negara, walau pun dalam rumusannya terdapat perbedaan, bahkan pada masa era reformasi ini juga Pancasila tetap dipertahankan sebagai sebagai weltanschauung, philosophische gronslag atau pandangan hidup bangsa dan dasar Negara Indonesia, hal ini ditandai dengan kesepakatan nasional tidak mengobahnya Pembukaan UUD $1945 .{ }^{14}$ Tidak diubahnya pembukaan UUD 1945 karena pembukaan UUD 1945 ini merupakan satu kesatuan dengan proklamasi kemerdekaan Indonesia dan kemerdekaan bangsa Indonesia merupakan rahmat Tuhan Yang Maha Esa pada bangsa Indonesia. ${ }^{15}$

Ketegasan bahwa Pancasila sebagai dasar negara dan sumber hukum dasar, termasuk untuk membuat konstitusi atau amandeman atas UUD 1945, dapat terlihat dari ketentuan Pasal 1 ayat (3) Tap MPR Nomor III/ MPR/2000 tertanggal 18 Agustus 2000 yang dengan tegas mengamanatkan bahwa sumber dasar hukum nasional adalah Pancasila sebagaimana yang tertulis di

"Perlunya weltanshauuing, philosophische, atau pandangan hidup bangsa sebagaimana yang dikemukakan oleh Ir. Soekarno dalam sidang BPUPKI tanggal 1 Juni 1945 atas pertanyaan Ketua BPUPKI tantang dasar negara Indonesia merdeka. Lihat. Muhammad Thalib, Irfan S.Awwas (ed). 1999. Doktrin Zionisme dan Idiologi Pancasila Menguak Tabir Pemikiran Politik Founding Father RI. Yogyakarta: Widhah Press.HIm. 62-63.

${ }^{12}$ Kansil. 2002. Pancasila dan Undang-Undang Dasar 1945. Jakarta: Pradnya Paramita. HIm. 67.

${ }^{13}$ Perdebatan tentang dasar negara Indonesia pernah terjadi dalam sidang Konstituante 7 Desember 1957. Lihat Ni'matul Huda. Op.Cit. Hlm. 49-50. S.Silalahi. Op.Cit. Ḧm. xi.

${ }^{14}$ Pasal 1 ayat (3) Tap MPR Nomor III/MPR/2000 tanggal 18 Agustus 2000 yo Tap MPR No.XVIII/MPR/ 1998.

${ }^{15}$ Dahlan Thaib.Op.Cit. HIm. 7. 
dalam Pembukaan-Undang-Undang Dasar 1945. Dalam ketentuan pasal ini secara ekspilisit ditegaskan sumber hukum dasar nasional adalah Pembukaan UUD 1945, dan batang tubuh UUD 1945 , dengan demikian penjelasan UUD 1945 bukan merupakan sumber hukum dasar nasional. Konsekwensi dari ketentuan Tap MPR tersebut semua aktivitas berbangsa' dan bernegara harus tetap mengacu kepada nilai-nilai Pancasila, dengan demikian termasuk di dalamnya untuk menentukan konsep demokrasi sesuai dengan substansi demokrasi itu sendiri. Inti dari itu semua adalah ber-hubungan dengan bagaimana hak dan kewajiban bangsa Indonesia diformat dalam bentuk yang lebih kongkerit dalam suatu tatanan demokrasi dan hukum di Indonesia.

\section{Pemilihan Presiden secara Langsung}

Adanya gagasan, amandemen ketiga UUD 1945, tentang pemilihan Presiden secara langsung pada pemilu tahun 2004 perlu dikaji secara teoris politik dan hukum. Pengujian dimaksudkan apakah Presiden dipilih langsung oleh rakyat telah sesuai dengan sistem politik, demokrasi, yang berlaku menurut sumber hukum dasar nasiona! bangsa Indonesia.

Gagasan pemilihan Presiden secara langsung oleh rakyat merupakan perubahan yang pundamental dalam mekanisme demokrasi di Indonesia, hal ini terjadi, mungkin disebabkan, trauma isțilah demokrasi terpimpin pada masa pemerintahan Presiden Soekarno dan istilah demokrasi Pancasila pada masa pemerintahan Presiden Suharto yang mengkonsentrasikan kekuasaan kepada lembaga kepresidenan. Amin Rais, mengusulkan agar demokrasi tidak diembelembeli dengan kata sifat seperti yang terjadi selama ini (yakni âda demokrasi terpimpin dan ada demokrasi Pancasila) sebab penyipatan itu selalu digunakan untuk memanipulasi mekanisme demokrasi itu sendiri sehingga prinsip demokrasinya menjadi hilang. ${ }^{16}$

Sebagaimana disebutkan di atas, menguji apakah gagasan pemilihan Presiden secara langsung oleh rakyat, mau tidak mau, suka atau tidak suka, sebagai konsekuensi Tap MPR Nomor III/MPR/2000 tanggal 18 Agustus 2000, harus diuji dengan Sila kempat dari Pancasila, sebagai causa norma dasar politik dan hukum dalam berbangsa dan bernegara di Indonesia.

Ada beberapa alasan Sila keempat ini dipergunakan sebagi causa norma atau batu uji dalam menguji gagasan Presiden langsung dipilih oleh rakyat, yaitu:

1. Inti pokok studi politik membutuhkan wawasan filosofi.

2. Pancasila merupakan sumber hukum dasar nasional, politik dan dasar negara yang mengandung nilai-nilai luhur bangsa Indonesia.

3. Menjaga konsistensi tertib hukum

4. Sila keempat dari Pancasila sangat erat hubungannya mekanisme demokrasi di Indonesia atau dengan kata lain, cara bagaimana hak dan kewajiban bangsa Indonesia diaplikasikan dalam aktivitas nyata kehidupan politik dan sistem

${ }^{16}$ Moh.Mahfud MD. 1999. Hukum dan Pilar-pilar Demokrasi. Yogyakarta: Gama.Media. HIm. 52. 
ketatanegaraan Indonesia, itu semua berkaitan dengan mekanisme demokrasi bagi bangsa Indonesia. ${ }^{17}$

Menguji gagasan pemilihan Presiden secara langsung oleh rakyat dapat di tinjau dari dua sisi, pada satu sisi dikaji melalui politik, berkenaan dengan demokrasi, dan pada sisi melalui hukum sebagai acuan legalisasi gagasan tersebut. Hal yang demikian wajar dilakukan karena antara politik dan hukum ibarat dua sisi dari sekeping mata uang. ${ }^{18}$

Secara literal, demokrasi berarti kekuasaan oleh rakyat. Secara historis, istilah demokrasi telah dipergunakan pada masa Yunani kuno yaitu sekitar abad ke-5 SM yang pada awalnya sebagai respons terhadap pengalaman buruk monarki dan kediktatoran di Negara-negara Kota Yunani kuno. Pada masa itu, demokrasi dipraktikkan sebagai sistem di mana seluruh warga negara membentuk legislatif, dan belum dikenal pembagian keku-asaan dalam negara.

Konsep demokrasi sejak kemunculannya pada zaman Yunani Kuno hingga kini tidak pemah habis-habisnya dibahas, pengembangan dan penyempurnaan konsep demokrasi terus bermunculan, juga teori-teori demokrasi terus dibicarakan dan selalu ditinjau ulang. Hal ini terjadi karena realisasi konsep demokrasi yang ada dinilai tidak memenuhi harapan rakyat bahkan menjurus penindasan terhadap rakyat, menimbulkan kesejenjangan, itu semua bertentangan dengan makna demokrasi itu sendiri yang bertujuan untuk menciptakan keseimbangan sebagaimana dikatakan Dony Gahral Adian demokrasi itu perlu didemokratisasi guna membuatnya sungguhsungguh tidak memihak. ${ }^{19}$ Pembaharuan konsep demokrasi ini sebagaimana terlihat dari gagasan Carol C.Gould dalam bukunya berjudul Rethingking Democracy. ${ }^{20}$

Kajian masalah demokrasi berkaitan erat dengan ide atau faham suatu negara, dan untuk itu pada tulisan demokrasi di Indonesia tegas dikatakan merupakan demokrasi Indonesia dengan mekañisme perwakilan, sebagai terpateri pada Sila keempat Pancasila, jadi tidak pada temipatnya untuk memberi makna lain atas istilah demokrasi dalam tulisan ini, karena itu merupakan konsep dasar demokrași Indonesia, selain itu pemberian definisi terhadap istilah demokrasi sangat sulit, sebagaimana dikatakan Masykuri Abdillah, bahwa demokrasi sebenarnya sangat sulit untuk didefinisikan secara tepat. ${ }^{21}$

${ }^{17}$ Sila keempat ini mengandung arti bahwa rakyat dalam menjalankan kekuasaannya, dilakukan melalui perwakilan, jadi tidak langsung. Keputusan-keputusan yang diambil oleh wakil-wakil itu dilakukan melalui musyawarah yang dipimpin oleh akal sehat serta penuh rasa tanggung jawab baik kepada Tuhan Yang Maha Esa maupun kepada rakyat yang diwakilinya. Kansil. Op. Cit. Hlm. 119.

${ }^{18}$ Mahfud MD. Op. Cit. HIm.1.

${ }^{19}$ Kompas. 11 Mei 2002.

${ }^{20}$ Telah diterjemahkan kedalam bahasa Indonesia oleh Samodra Wibawa. 1993. Demokrasi Ditinjau Kembali. Yogyakarta: Penerbit Tiara Wacana. Lihat juga buku.SP.Varma. "Modern Political Theory." Yohanes Kristiarto SL. Dkk. 2001. Toeri Politik Modern. Jakarta: Penerbit Rajawali Pers.

${ }^{21}$ Masykuri Abdillah. 1999. Demokrasi Di Persimpangan Makna, Respons Intelektual Muslim Indonesia Terhadap Konsep Demokrasi (1966-1993). Yogyakarta: Tiara Wacana Yogya. HIm. 87. 
Pada tulisan ini hanya menguji gagasan pemilihan Presiden secara langsung apakah sesuai dengan mekanisme yang dimintakandalam Sila keempat dari Pancasila.

Secara umum, corak demokrasi di dunia ini ada dua corak yang menonjol, yaitu demokrasi liberal berbasis pada nilai kebebasan individu yang bermuara dari persamaan dalam hukum, dan demokrasi sosialis berbasis nilai persamaan sosial. Pada intinya ke-munculan demokrasi, liberal, bermula dari premis bahwa kebebasan individu merupakan nilai utama yang harus dilindungi oleh pemerintah. Dikemukakan juga bahwa hak kepe-milikan pribadi harus dilindungi oleh negara. Pandangan ini dikembangkan menjadi teori demokrasi politik, yang mengharuskan negara menjamin kebebasan sipil dan hak-hak politik secara sama bagi setiap orang. Seluruh kegiatan, baik ekonomi, sosial, dan pribadi, dipahami lebih sebagai persoalan pribadi daripada sebagai persoalan publik, dan oleh karenanya di luar wilayah keputusan politik. ${ }^{22}$

Sedangkan pada demokrasi sosialis didasarkan pada teori menekankan sentralisasi kepentingan sosial atau kepentingan bersama, dalam bentuk kepentingan kelas mau pun solidaritas manusia, sebagai motif bertindak. Jadi teori sosialis mengusulkan persamaan sosial dan ekonomi dan kooperasi sosial sebagai norma bagi masyarakat yang baik. Penerapan teori menyebabkan perlunya kekuasaan negara yang kuat dan terpusat dan perlunya perencaniaan ekonomi yang terpusat pula. ${ }^{23}$

Masing-masing paham di atas, secara teoritis, bagaikan dua kutup yang tidak dapat disatukan dan saling bertentangan. Kẹdua paham demokrasi tersebut pada Kenyataannya tidak mampu menciptakan keseimbangan di tengah-tengah masyarakat bahkan menimbulkan dampak negatif.

Pada demokrasi liberal berakibat muncul manusia sebagai individu yang asosial dan egois, yang motivasi utamanya dalam bertindak adalah pemenuhan kepentingan sendiri. Selain itu individualisme liberal gagal menangkap sifat sosial kegiatan manusia, atau bahkan meligitimasi model-model perilaku yang antisosial dan keakuan, sesuatu yang tidak dapat diterima secara moral. Di samping itu diberinya dukungan dan pembenaran ter-hadap ketimpangan kehidupan sosial dan ekonomi, dengan melindungi hak untuk me-numpuk kekayaan pribadi secara tak terbatas tanpa memperhatikan akibat sosialnya. ${ }^{24}$

Pada demokrasi sosialis, juga muncul kritikan karena demokrasi yang demikian itu

${ }^{22}$ Carol C.Goul. 1993. Demokrasi Ditinjau Kembali. Terjemahan. Yogyakarta: Tiara Wacana. HIm. 4.

23lbid. Hlm. 6.

${ }^{24}$ lbid. Sebagai contoh: gerakan hak-hak sipil Amerika Serikat tahun 1960-an berujung pada perluasan lingkup kebebasan bagi kaum kulithitam. Perluasan yang ditandai dengan disahkannya undang-undang yang melarang praktik-praktik segregasi rasial. Hak sipil dan politik kaum hitam ini kini dijamin setara. Namun kenyataannya, reformasi legal itu tidak banyak membantu. Statistik menunjukkan tetap rendahnya jumlah siswa kulit hitam yang melanjutkan ke universitas. Kemiskinan dan rendahnya mutu sekolah telah menjerat kesempatan mereka untuk mengenyam pendidikan tinggi. 
membiarkan dan bahkan mengijinkan berlakunya kekuasaan negara yang otoroter dan digencetnya kebebasan individu dan demokrasi politik, munculnya hierarkhi dan stratifikasi sosial dan ekonomi, selain itu terciptanya karakteristik ekonomi komando dan perencanaan terpusat dan hal ini tidak efisien. ${ }^{25}$

Bila dicermati antara demokrasi liberal dan demokrasi sosialis dalam pembahasan demokrasi kontemporer saat ini ada satu substansi yang sama yang dijadikan acuan dalam menentukan demokrasi kontemporer saat ini, yaitu perlindungan terhadap hak kepemilikan atas benda, materi, kekayaan atau tegasnya bertumpu pada aspek ekonomi dan hal ini berkembang pada konsep demokrasi kontemporer saat ini. Artinya demokrasi selalu berdampingan erat dengan paham ekonomi, konsep kepemilikan. Demokrasi. liberal diiringi paham kampitalisme, sedangkan demokrasi sosialis diiringi paham ekonomi kolektif.

Dua faham demokrasi tersebut dalam realitanya saling bersaing dan berupaya untuk menyebarkan pengaruhnya kepada sistem politik pada negara-negara yang ada di dunia ini. Kelihatannya paham demokrasi liberal dengan paham kapitalisme, akibat peng-aruh globalisasi, tampil sebagai pemenangnya, dan ini menandakan berakhirnya sejarah, sebagaimana yang diungkapkan Francis
Fukuyama, ahli sosiologi Amerika Serikat, yang mengatakan kemenangan paham kapitalisme dan demokrasi liberal mungkin merupakan "titik akhir evolusi idiologis umat manusia", dan "bentuk final pemerintahan manusia", sehingga ia dapat disebut sebagai "akhir sejarah". $^{28}$

Peluang menyebarluasnya paham demokrasi liberal dan kapitalisme semakin kuat akibat-dimungkinkan akibat kemajuan teknologi, khususnya di bidang komunikasi dan informasi, yang dikuasai dan didominasi Amerika Serikat yang berpaham liberalisme dan kapitalisme, yang membawa dampak era globalisasi (kejagatan) di segala bidang termasuk globalisasi komunikasi dan informasi.

Dalam beberapa dasawarsa akhir-akhir ini, globalisasi komunikasi dan informasi kian jauh menyentuh sistem nasional nasional semua negara. Akibatnya, banyak masalah baru yang ditimbulkan. Di antaranya yang menonjol adalah masalah politik dan kebudayaan. Keberadaan globalisasi komunikasi dan informasi seakan-akan mengkongretkan penerapan Pasal. 19 Pernyataan Umum Hak-Hak Asasi Manusia di bidang informasi. Di pihak lain, ketentuan Pasal 19 Pernyataan Umum Hak-Hak Asasi Manusia itu memberi landasan hukum terhadap globalisasi dan informasi. ${ }^{27}$

\section{- 25/bid. HIm. 7.}

${ }^{26}$ Fancis Fukuyama. 2001. Kemenangan Kapitalisme dan Demokrasi Liberal. Terjemahan. Yogyakarta: Qalam. HIm.1.

${ }^{27}$ A.Muis. "Titian Jalan Demokrasi, Peranan Kebebasan Pers Untuk Budaya Komunikasi Politik." Kompas. 2000. HIm. 37. Lihat tuntutan demonstran anti RUU Penyiaran yang dinilai merampok hak masyarakat untuk mendapatkan informasi. Kedaulatan Rakyat. 16 Mei 2002. HIm.1. 
Pengaruh globalisasi informasi atau pemberitaan antar bangsa dewasa ini mengakibatkan sistem nasional atau batas-batas negara kian menipis, dan hal ini juga melanda bangsa Indonesia, khususnya di bidang politik. Globalisasi informasi dan komunikasi melakukan penetrasi terhadap bangsa Indonesia untuk meniru, sadar atau tanpa sadar, negara-negara yang berpaham liberlisme dan kapitalisme. ${ }^{28}$ Padahal, tidak ada bangsa yang sudi kehilangan jatidiri, tidak ada yang sudi kehilangan wawasan nasionalisme, kebudayaan dan lembaga-lembaga agama. Tidak ada negara yang bersedia menghilangkan sistem politiknya. ${ }^{29}$

Salah satu pengaruh demokrasi liberal yang kelihatan saat ini dalam sistem politik di Indonesia "mungkin" terlihat pada gagasan pemilihan presiden secara langsung oleh rakyat pada pemilu 2004 yang akan datang sebagai hasil amandemen UUD $1945 .^{30} \mathrm{Apa}$ bila ini terjadi amandeman tersebut perlu diuji keabsahannya berdasarkan philosophische gronslag atau pandangan hidup bangsa, Pancasila yang oleh Tap MPR Nomor III/MPRI 2000 tanggal 18 Agustus 2000 diamanatkan sebagai sumber hukum dasar nasional. Atau nilai-nilai luhur bangsa Indonesia, khususnya
Sila keempat telah luntur dan memudar atau hilang sama sekali, sebagaimana yang dikatakan oleh Keebet von Benda-Beckmann dalam disertasinya yang berjudul Goyahnya Tangga Menuju Mufakat. ${ }^{31} \mathrm{Di}$ sini terlihat pergulatan antara, hukum dan politik semakin nyata terlihat, dan mampukan hukum berperan untuk melakukan kontrol terhadap perubahan masyarakat.

Dalam membuat suatu undang-undang, konstitusi, agar berlaku efektif dan tercapai tujuan yang hendak diinginkan oleh undangundang, konstitusi, minimal harus diperhatikan tiga hal utama, yaitu:

1. Filosofi yang melandasi undang-undang tersebut

2. Tertib hukum berkenaan dengan kaedah, norma, hukumnya, dan

3. Masyarakat hukumnya. ${ }^{32}$

Ketiga unsur îni saling mengisi dalam porsi yang seimbang dalam mengisi suatu undang-undang, konstitusi, yang akan dibentuk.

Sekarang, marilah dilihat, satu-persatu syarat tersebut dalam gagasan pemilihan Presiden secara langsung oleh rakyat atas amandemen atas UUD 1945. Pertama,

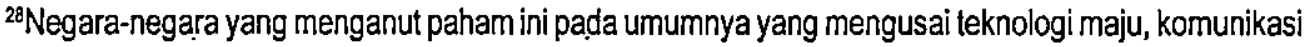
dan informasi.

${ }^{29}$ Muis. Op.Cit. HIm. 38 catatan Perumusan Panitia Ad Hoc.I tanggal 5 April 2002

${ }^{30}$ Asumi ini diperkuat lagi catatan RapatPerumusan Panitia Ad.Hoc.l, tanggal 5 April 2002, tentang Pemisahan wilayah dari Negara Kesatuan Republik Indonesia hanya dimungkinkan melalui referendum nasional. Ketentuan ini menghilangkan faham kebangsaan dan terkesan ada pluralisme kebangsaan di Negara Indonesia, dan secara kaedah hukum ketentuan ini sangat bertentangan dengan jiwa Pembukaan UUD 1945.

${ }^{31}$ Judul Aslinya The Broken Stainways To Consensus: Village Justice and State Courts, diterjemahkan ke dalam bahasa Indonisia oleh Indira simbolon, diterbitkan oleh PT.Grasindo.

${ }^{32}$ Lihat juga pendapat Juniarto yang dikutip Ni'matul Huda. Op.Cit. HIm. 60-61. 
tentang dasar filosofis. Acuannya adalah Pancasila sebagai philosophische gronslag atau pandangan hidup bangsa, khususnya Sila keempat dari Pancasila yang mengamanatkan: "Kerakyatan yang dipimpin oleh hikmat kebijaksanaan dalam permusyawaratan/ perwakilan". Filosofi suatu bangsa sangat menentukan demokrasi dari suatu bangsa. Hal ini juga berarti bahwa demokrasi tidak hanya berhubungan dengan institusi formal tetapi juga dengan eksistensi nilai-nilainya dalam kehidupan sosial dan politik. ${ }^{33}$

\section{Sila keempat}

secara tegas mengungkapkan fhilosofi dari mekanisme demokrasi yang berlaku menurut jiwa banigsa Indonesia, yaitu demokrasi perwakilan. ${ }^{34}$ Unsur perwakilan tersebut diperkuat lagi dengan ciri yang khas yaitu musyawarah sebagai dasar dari bentuk khusus demokrasi di Indonesia. ${ }^{35}$ Pada tingkat musyawarah masing-masing hak individu diakui keberadaannya, tetapi masingmasing individu tidak mendominasi individu lainnya, yang lebih diutamakan adalah kebenaran yang didasarkan pada kausa nilainilai moral dan agama yang dianut oleh bangsa Indonesia yang diyakini kebe-narannya yang patut dan mungkin diterapkan. Dalam menemukan kebenaran dalam musyawarah diolah berdasarkan kematangan berfikir, kearifan, perenungan mendalam, kebijaksanaan, dan kecermatan memahami nilai-nilai sosial dan etis. ${ }^{36}$

Esensi musyawarah sebenarnya adalah keseimbangan antara individu dengan kolektif. Dan musyawarah ini kelihatannya menjadi dasar pemikiran peninjauan kembali teori tentang konsep demokrasi yang saat ini dalam teori demokrasi kontemporer telah melahirkan teori demokrasi partisipasi (participatory democracy) yang dikembangkan oleh Schumpeter berdasarkan dasar filosofis dari John Dewey. ${ }^{37}$

Sila keempat dari Pancasila merupakan corak dasar kehidupan bermasyarakat di Indonesia dan sila ini telah tertanam dalam hati sanubari bangsa Indonesia hingga saat

${ }^{33}$ Masykuri Abdillah. Op.Cit. Hlm. 75.

${ }^{34}$ Budaya yang melekat pada bangsa Indonesia adalah menyerahkan segala-galanya kepada pada seorang pemimpin, dan budaya ini masih melekat hingga saat ini, lihat Baskara T.Wardaya, (ed). 2001. Menuju Demokrasi Politik Indonesia Dalam Perspektif Sejarah. Jakarta: Gramedia. Hlm. 75. sebaliknya pemimpin merasa dirinya sebagai individu menyatu dan bagian dari masyarakat.

${ }^{35} \mathrm{Keosnoe}$, sebagaimana dikutip oleh Keebet von Benda-Beckmann. Op.Cit. HIm. 2.

${ }^{36}$ Lihat pendapat M.Natsir, Z.A.Ahmad, Jalaluddin Rahmat, Amin Rais, dll, yang berpendapat musyawarah merupakan demokrasi, dalam Masykuri Abddillah: Op.Cit. Hlm. 76-81. dalam pepatah Minangkabau disebutkan, Kemanakan beraja ke mamak, mamak beraja ke penghulu, penghulu beraja ke mufakat, mufakat beraja ke alur, alur beraja ke yang mungkin dan patut, mungkin dan patut beraja ke yang benar, kebenaran itulah yang menjadi raja, bandingkan dengan pendapat Carol C.Gould yang menyatakan dasar teori demokrasi baru saat ini adalah landasan filosifis dan etis.

${ }^{37}$ Varma. Op.Cit. Hlm. 218. lihat juga Carol C.Goul dikatakannya demokrasi partisipasi ini dikembangkan baik pada. paham individualis maupun sosialis, dalam carol C.Goul. Op.Cit. HIm. 287-288. 
ini, dan hal ini sebagaimana terlihat dalam konsep ketatanegaraan hukum adat, yakni konsep Dalihan Na Tolu dan Tiga Tali Nan Sapilin. ${ }^{38}$

Esensi dari konsep ini adalah tidak ada dominasi kekuasaan yang dilakukan oleh salah satu lembaga kekuasan, misalnya oleh legislatif, eksekutif, atau yudikatif. Ketiga kekuasaan ini berdiri sejajar, seimbang dan saling mengisi, lembaga yang paling tinggi adalah pada lembaga musyawarah yang di dalamnya terdapat unsur eksekutif, legislatif, dan yudikatif.

Masalahnya, apakah filosofi seperti ini masih bertahan dan tetap merupakan nilai luhur bangsa Indonesia, atau memang sudah usang sehingga harus diberi arti baru? Hal ini perlu dilakukan penelitian lebih jauh secara seksama, objektif, dan penuh kearifan. Namun sepanjang redaksional Sila Keempat dari Pancasila tetap sebagaimana tertera selama ini, maka secara juridis formal, filosofis dari nilai demokrasi, pada Sila keempat tersebut tetap bermakna musyawarah dan demokrasi perwakilan.

Bila dicermati secara mendalam, sistem perwakilan ini juga tercermin dari paham yang melandasi sila-șila dari Pancasila, yaitu Ketuhanan Yang Maha Esa mewakili paham keagamaan, Kemanusiaan Yang Adil dan Beradab mewakili paham individualisme, dan. Keadilan Sosial bagi seluruh Rakyat Indonesia: mewakili paham sosialisme. ${ }^{39}$ Ketiga paham ini tidak dapat mendominasi satu săma lainnya, tetapi berjalan seimbang dalam suatu forum musyawarah, dan sebagaimana disebutkan di atas musyawarah ini merupakan demokrasi yang khas Indonesia. Dan di samping itu akibat tiga paham yang pada dasarnya bertolak belakang itu terletak pada satu wadah yang pada dasarnya saling berbenturan, maka tepat mekanisme dari demokrasi Indonesia adalah musyawarah dan perwakilan.

Apabila argumentasi ini dapat diterima, maka pemilihan Presiden. secara langsung oleh rakyat pada Pemilu yang akan datang tidak sesuai dengan falsafah bangsa atau bertentangan dengan nilai-nilai yang dianggap benar oleh bangsa Indonesia, oleh karena itu secara filosofis, aktivitas pólitik memilih Presiden secara langsung telah melanggar atau setidak-tidaknya telah memberi arti baru atas isi Sila keempat dari Pancasila, apabila

${ }^{38}$ Dalihan Na Tolu pada masyarakat Batak yang menganut sistem patrilinial dan Tiga Tali Nan Sapilin pada masyarakat Minangkabau yang menganut sistem matrilineal. Konsep tersebut adalah tiga kekuasan dalam suatu masyarakat, hal ini sama dengan Trias Politika yang dikembangkan Montesqeu. Berdasarkan konsep Dalihan na tolu dan Tiga tali na Sapilin kedaulatan di tangan rakyat, bukan pada negara. Penggunaan konsep ini beranjak dari pendapat Daniel S.Lev yang mengatakan: Penelitian yang terpenting dalam bidang hukum (dan politik juga) di Indonesia pada akhirnya harus, dan akan, dibuat oleh para sarjana Indonesia sendiri. Karena seorang sarjana asing, walaupun merasa terlibat dan ingin mennyumbangkan sesuatu yang berharga, pada akhirnya tidak mungkin merasakan (dan melayani) sedalam-dalamnya semua persoalan dan harapan yang masuk dalam imajinasi masyarakat sana. Daniel S.Lev. 1990. Hukum dan Politik di Indonesia. Terjemahan. Jakarta: LP3ES. HIm. xxiv.

${ }^{39} \mathrm{Lihat}$ pidato Soekamo pada tanggal 1 Juni 1945 tentang Pancasila, dan lihat juga pendapat Daneil S.Lev dikutip Adnan Buyung dan dikutip kembali oleh Ni'matul Huda. Op.Cit. HIm. 55. 
ini terjadi, secara teoretis, konsekwensinya bangsa Indonesia secara diam-diam telah mencabut dan harus merubah redaksi dan isi dari Sila keempat Pancasila, sebagai landasan sistem politik dan ketatanegaraan bangsa Indonesia dalam mengisi hak dan kewajibannya. Dan ini merupakan perubahan yang radikal atas philosophische gronslag atau pandangan hidup bangsa Indonesia dengan demikian membuktikan bangsa Indonesia tidak konsisten dengan keputusannya sebagaimana tertera dalam Tap MPR Nomor XVIII/MPR/1998 tanggal 13 Novermber 1998 yo Tap MPR Nomor III/MPR/2000 tanggal 18 Agustus 2000 yang berprinsip tetap mempertahankan Pancasila sebagai dasar philosofi bangsa.

Dalam demokrasi langsung diperlukan sekumpulan warga negara yang berjumlah relatif kecil yang bisa diakomodasi dalam suatu perkumpulan tunggal, yang memiliki waktu cukup serta kebebasan dari tanggung jawab lain agar bisa memahami bukti dan argumen-argumen yang perlu untuk mengambil keputusan politis yang sehat. Tidak satu pun tuntutan demokrasi langsung itu dapat dipenuhi oleh lembaga-lembaga kenegaraan masa kini, meskipun ada ruang bagi keterlibatan warga negaranya dalam pembuatan keputusan langsung di tingkat nasional melalui pemilihan umum dan reperendum, dan ruang untuk partisipasi yang lebih berkelanjutan dalam pembuatan keputusan di tingkat-tingkat yang sangat lokal. ${ }^{40}$
Kedua, tertib hukum berkenaan dengan norma atau kaedah hukumnya. Dari sisi norma atau keedah hukum, suatu undang-undang, konstitusi, disyaratkan agar isi norma'yang satu dengan isi norma yang lain, haruslah tidak terdapat pertentangan di dalamnya. Artinya ketentuan undang-undang yang lebih rendah tidak boleh bertentangan dengan ketentuan undang-undang yang lebih tinggi, dan ketentuan undang-undang yang lebih tinggi tidak boleh pula bertententangan dengan nilainilai yang: dianggap benar, atau dengan kata lain tidak boleh bertentangan dengan sumber hukum filosifisnya. ${ }^{41}$ Artinya isi norma hukum baik secara vertikal mau pun horizonital tidak boleh ada yang bertentangan.

Dalam konsideran Tap MPR Nomor IIII MPR/2000 tanggal 18 Agustus 2000 ditegaskan antara lain, bahwa dalam penyelenggaraan berbangsa dan bernegara, sup-remasi hukum haruslah dilaksanakan dengan sungguhsungguh, dan untuk mewujudkan supremasi hukum perlu adanya aturan hukum yang merupakan peraturan perundang-undangan yang mengatur kehidupan bermasyarakat, berbangsa, dan bernegara sesuai dengan tata urutannya.

Secara formal, tata urutan peraturan perundang-undangan yang berlaku di Indonesia adalah sebagaimana dijabarkan dalam Pasall 2 Tap MPR Nomor Ill/MPR/2000 tanggal 18 Agustus 2000 yang mengamanatkan: HIm. 26.

${ }^{40}$ David Beetham, Kevin Boyle. 2000. Demokrasi: 80 Tanya Jawab. Terjemahan. Yogyakarta: Kanisius.

${ }^{41}$ Sesuai teori stufen Kelsen, bandingkan dengan prinsip tertib hukum dalam hukum adat yang tertuang dalam pepatah: berjenjang naik bertangga turun. 
Tata urutan peraturan perundangundangan merupakan pedoman dalam pembuatan aturan hukum di bawahnya.Tata urutan peraturan perundang-undangan Republik Indonesia adalah:

1. Undaning-undang Dasar 1945;

2. Ketetapan Majelis Permusyawaratan Rakyat Republik Indonesia;

3. Undang-undang;

4. Peraturan Pemerintah Pengganti Undang-undang (Perpu);

5. Peraturan Pemerintah;

6. Keputusan Presiden

7. Peraturan Daerah.

Berdasarkan tata urutan ini, dapatlah jadikan dasar untuk menguji secara formal landasan kaedah hukum yang melandasi pemilihan Presiden secara langsung oleh Rakyat. Kaedah hukum dari Prinsip Kedaulatan rakyat ditafsirkan oleh Jimly Asshidiqie dan Dahlan Thaib, yang pada intinya rakyat secara langsung terlibat dalam menentukan jalannya pemerintahan, memimpin jalannya pemerintahan dan menentukan sifat strategis dan mendasar pada konstitusi. ${ }^{42}$ Penafsiran. ini, bila tidak keliru, kelihatannya menganùt paham indivisualisme murni hal ini terlihat sekali pada pemilihan Presiden langsung dan referendum.

Secara sumber filosofis, telah disebutkan di atas, bahwa demokrasi Indonesia adalah demokrasi khas Indonesia, kalau boleh disebutkan sebagai demokrasi yang unik, yaitu demokrasi yang menyeimbangkan berbagai paham yang ada di dunia ini, yaitu paham agama, paham individualisme, dan pahan' sosialisme. Keunikkannya inilah yang dicoba direalisasikan pada mekanisme demokrasi di Indonesia dan dalam aturan-aturan hukum, salah satu contoh keunikan kaedah hukum cerminan khas Indonesia adalah Undangundang Nomor 1 Tahun 1974, yang oleh Hazairin disebutkan univikasi yang unik.

Berpegang kepada tata urutan sebagaimana yang diamanatkan dalam TAP MPR Nomor III/MPR/2000 tanggal 18 Agustus 2000 , darajat yang tertinggi dalam perundangundangan Indonesia adalah UUD 1945. Bebarapa pasal dari UUD 1945 ini diamandemen demi tuntutan reformasi, melalui Tap MPR. Dengan tetap berpegang teguh kepada formalitas tata urutan perundang-undangan maka apabila akan merubah UUD 1945 yang dilakukan oleh MPR. MPR harus mengacu kepada ketentuan formal yang ada di dalam Undang-Undang Dasar apabila tidak ditemui; MPR harus mencari kaedah hukum yang terlihat pada esensi Pancasila sebagaimana yang tertuang di dalam pembukaan UUD 1945. Di sinilah pungsi hukum sebagai kontrol terhadap perubahan masyarakat.

Berajak dari itu, kaedah hukum yang termuat di dalam Pembukaan UUD 1945, khususnya kaedah hukum yang ada di dalam Sila keempat Pancasila yakni Kerakyatan yang dipimpin oleh hikmat kebijaksanaan dalam permusyawaratan/perwakilan, ${ }_{1}^{43}$ Dan norma

${ }^{42}$ Lihat-Jimly Assidiqie. Op.Cit. HIm. 22. lihat juga Dahlan Thaib. Op.Cit. Hlm. 12-13.

${ }^{43}$ Kaedah hukum ini akan terlihat jelas pada konsep Dalihan na Tolu dan Tiga talina sapilin dalam konsep ketata negaraan hukum adat. 
dasar ini dikonkritisasikan dalam bentuk aturan hukum pada Pasal 1 ayat (2) UUD 1945 yang menyebutkan: "Kedaulatan di tangan rakyat, dan dilakukan sepenuhnya oleh Majelis Permusyawaratan Rakyat". ${ }^{44}$

Pasal 1 ayat (2) UUD 1945 tersebut isi kaedah hukumnya jelas mengamariatkan demokrasi Indonesia adalah demokrasi perwakilan selaras dengan Sila kempat Pancasila. Kedaulatan rakyat diartikan demokrasi, Jadi, secara juridis formal dan berdasarkan, nor-ma atau kaedah hukum dasar kelihatannya pemilihan Presiden secara langsung oleh rakyat bertentangan dengan ketentuan kaedah hukum UUD 1945 (Pasal 1 ayat (2). Dan kehendak Tap MPR Nomor IIII MPR/2000 tanggal 18 Agustus 2000. Suatu konstitusi yang baik tidak boleh terdapat pertentangan isi kaedah hukum di dalamnya. Dengan demikian dari segi kaedah hukum, tata urutan hukum, pemilihan Presiden secara langsung oleh rakyat tidak dibenarkan dan bertentangan dengan rasa keadilan dan kepatutan yang ada pada rakyat Indonesia. Bukankah kesepakatan yang bertentangan dengan undang-undang kehilangan daya ikatnya.

Memang diakui, secara juridis formal, MPR berwenang mengganti UUD, sebagaimana di amanatkan oleh ketentuan Pasal 37 UUD 1945, tetapi perlu dipertanyakan pula, berwenangkah MPR merubah kaedah hukum, asas hukum, filosifi, yang mendasari UUD tersebut; - artinya berwenangkah MPR mengenyampingkan philosophische gronslag atau pandangan hidup bangsa dalam membuat atau merubah konstitusi?, Untuk menguji ini, mungkin di sinilah peranan Mahkamah Konstitusi yang akan datang.

Dengan perpegang kepada pendapat Mahfud MD yang menyebutkan Demokrasi tanpa hukum tidak akan terbangun dengan baik bahkan mungkin menimbulkan anarki, sebaliknya hukum tanpa sistem politik yang demokrasi hanya akan menjadi hukum yang elitis dan repressif. Bagaimana bentuk dan mekanisme yang diinginkan dari suatu gagasan tentang demokrasi tentu harus dituangkan di dalam aturan-aturan hukum dan kepada aturan-aturan hukum itulah setiap konflik dalam berdemokrasi harus dicari rujukannya, ${ }^{4} 5$ Mampukah hukum melakukan peranannya sebagai pengontrol perubahan? Masihkah politik determinan terhadap hukum?

Kelihatannya, di Indonesia, pertarungan antara polilitik dan hukum tetap berkelan-jutan dan semakin sengit, hal ini terlihat kehendak politik, melakukan pemilihan presiden secara langsung dan referendum berhadapan dengan kehendak menegakkan supremasi hukum. Kelihatannya melahirkan demokrasi ibarat seorang ibu yang melahirkan seorang anak, yakni penuh kecemasan, kesakitan dan kenikmatan.

${ }^{44}$ Lihat Rancangan Perubahan Keempat Undang-Undang Dasar 1945 Hasil Perumusan Panitia Ad Hoc I Badan Pekerja MPR tanggal 3-7 April 2002. dan juga bandingkan dengan konsep Undang-Undang Dasar Negara Kesatuan R.I yang diusulkan oleh Jimly Asshidiqie. Op.Cit. Hlm. 34.

${ }^{45}$ Mahfud MD. Pilar-pilar... Op.Cit. HIm.1. dari redaksi tersebut terlihat fungsi hukum adalah sebagai alat perubah dan alat pengontrol perubahan. 
Ketiga, Aspek masyarakat. Sikap, corak, pemikiran, dan budaya yang dianut masyarakat juga sangat menentukan apakah pemilihan Presiden secara langsung tepat diterapkan pada Pemilu 2004 mendatang.

Sistem Pemilu memilih Anggota Lembaga Perwakilan Rakyat dikenal dua sistem, yakni: (a) Sistem pemilihan organis; (b) Sistem Mekanis. Sistem terakhir ini dilaksanakan dengan dua sistem pemilihan pula, yaitu (1) Sistem Pemilihan Distrik; (2) Sistem Pemilihan Proporsional. Aturan tentang pemilihan Lembaga Perwakilan Rakyat ini bukan merupakan kajian dalam makalah ini, karena hal ini juga pada politik praktisnya tidak menimbulkan masalah. Wolhof, ${ }^{46}$ memberi penjelasan tentang pokok pikiran atas sistem pemilihan organis dan mekanis, penerapan dari kedua sistem yang diajukan itu sangat bergantung dari sifat, corak, kualitas dan budaya rakyat suatu negara, di samping masalah hukum dan paham kenegaraan yang dianut oleh masyarakat tersebut.

Kajian dalam makalah ini berkenaan dengan melaksanakan Pemilu untuk menentukan seseorang menjadi pejabat negara, untuk ini dapat dibedakan menjadi dua, yaitu (a) Secara langsung; (b) Secara bertingkat (tidak langsung). ${ }^{47}$

Mengingat tingkat pendidikan masyarakat Indonesia yang bervariatif bahkan ada yang tidak mengenyam pendidikan dan masyarakat
Indonesia yang majemuk yang terdiri dari berbagai macam suku bangsa; Masing-masing mempunyai bahasa, nilai, budaya tersendiri dan berada pada geografi yang berbeda-beda pula serta hidup dalam budaya kolektif dengan pemikiran -kolektif pula. Pada dasarnya budaya kolektif dan berpikir kolektip ini menyerahkan kepada individu tertentu untuk memikirkan semuanya, sementara yang lain tidak perlu berpikir lagi, tegasnya budaya bangsa Indonesia itu Paternalisme; artinya sifat ketergantungan rakyat kepada pemimpinnya sangat besar sekali. Di samping itu, dikalangan elit masyarakat Indonesia terdapat pula budaya penguasa bebas dari kesalahan, hal ini sama artinya paham egoistis. ${ }^{48}$

Bangsa Indonesia lahir dan hidup dalam budaya yang menyebutkan diri to be is more important than to do (ada dan hadir lebih penting daripada bertindak). Konsekwensi dari ideal hidup demikian ini menyebabkan manusia Indonesia cenderung pasif, konvensional, dan dengan sendirinya tidak menyukai konflik, dan memiliki pandangan hidup agar hidup tenang dan bersahaja. ${ }^{49}$ Padahal melalui konflik itulah manusia Barat mengadakan perbaikan-perbaikan dalam rangka menjawab persoalan manusia. Idea dan cita-cita hidup bangsa Indonesia inilah yang menimbulkan hak-hak kolektif didahulukan dari hak-hak individu.

${ }^{46}$ Lihat B. Hestu Cipto Handoyo, Y.Thresianti. 2000. Dasar-Dasar Hukum Tata Negara Indonesia. Yogyakarta: Universitas Atma Jaya. Hlm. 135.

${ }^{47}$ Bandingkan juga dengan konsep hukum adat: berjenjang naik bertangga turun.

${ }^{48}$ Baskara T.Warda. Op.Cit. Hlm.118.

${ }^{49}$ Darji Darmohadiharjo, Shidarta, 2002. Pokok-pokok Filsafat Hukum, Apa dan Bagaimana Filsafat Hukum Indonesia. Jakarta: Gramedia. HIm. 80. 
Pandangan hidup yang demikian itu masih berjalan hingga saat ini, dan membawa pengaruh kepada sistem demokrasi yang di lahirkan di Indonesia. Sedangkan, büdaya individu dan berpikir individual adalah sesuatu. yang baru di Indonesia, budaya dan berpikir demikian itu mulai muncul pada zaman Chairil Anwar,dikenal sebagai pelopor pujangga baru, yang ditandai dengan sajaknya yang berjudul "Aku".

Dalam teori ilmu politik dewasa ini, dikembangkan karekter individu-individu mempunyai pengaruh terhadap persoalan politik, khususnya sikap demokratis. Artinya karakter individu-individu yang demokratis sebagai kondisi yang diperlukan bagi demokrasi..$^{50}$

Berpegang pada teori karakter individu yang mempengaruhi demokrasi di atas, apabila kita terapkan pada realitas keadaan masyarakat indonesia yang paternalistik dan budaya pemimpin tidak pernah salah, maka pemilihan Presiden secara langsung secara teoritis tidak akan menghasilkan pemerintahan yang demokratis. Oleh karena itu, untuk menguatkan partisipasi masyarakat, rakyat dalam proses demokratisasi di Indonesia harus dilakukan dua hal yang mendesak, yaitu:

1. Perubahan kesadaran rakyat, yang tadinya memandang diri mereka sebagai penerima pasif atas segala sesuatu yang diberikan oleh kekuasaan menjadi agenagen perubahan sosial yang aktif melalui bentuk partisipasi yang positif dalam proses peng-ambilan keputusan oleh negara.

2. Pengurangan secara besar-besaran segala ketimpangan yang ada. ${ }^{5}$

Akhirnya bangsa Indonesia saat ini berada pada problematik yang luar biasa, dan banyak menyisakan persoalan yang menanti jawaban, antara lain:

1. Berpeluangkah dekrit presiden muncul kembali?

2. Siapakah pemenang dari pergulatan politik dengan hukum?

3. Benarkah politik determinan terhadap hukum?

Namun, sebagai bangsa yang beragama, perlu diingat bahwa rakyat diperintah oleh Pemimpin dan Pemimpin diperintah oleh Tuhan, di sinilah akan muncul pemimpin yang demokratis. Bukankah dalam .Al Qur'an disebutkan, "setiap pemimpin akan dimintai pertanggungjawabannya?"

\section{Simpulan}

Gagasan Pemilihan Presiden secara langsung oleh rakyat tidak dibenarkan karena bertentangan dengan landasan dasar politik (landasan idiil, Pancasila) dan landasan yuridis formal sebagaimana tertuang dalam Pasal 1 ayat (2) UUD 1945: Dalam rangka penegakan supremasi hukum akan terjadi

50Sebagaimana yang dikembangkan oleh Alexis de Tocqueville, Walt Whitman, John Stuart Mill, dan Jon Dewey pada teoritisi individual, dan Kropotkon dan Reobert Owen pada teoritisi sosialis; dalam Carol C.Golud. Op.Cit. Him. 287-288.

${ }^{51}$ Varma. Op. Cit. HIm. 223. 
benturan antara kemauan politik dangan kehendak hukum dalam hal pemilihan Presiden secara langsung oleh Rakyat:

\section{Daftar Pustaka}

Abdillah, Masykuri. 1999. Demokrasi Di Persimpangan Makna, Respons Intelektual Muslim Indonesia Terhadap Konsep Demokrasi (19661993). Yogyakarta: Tiara Wacana. Yogya.

Asshiddiqie, Jimly. "Undang-Undang Dasar Negara Kesatuan Republik Indonesia, Pengantar Perubahan:". Makalah t.t.

Beetham, David, Kevin Boyle. 2000. Demokrasi: 80 Tanya .Jawab. Terjemahan. Yogyakarta: Kanisius.

Darmohadiharjo, Darji, Shidarta, 2002. Pokokpokok Filsafat Hukum, Apa dan Bagaimana Filsafat Hukum Indonesia. Jakarta: Gramedia.

Fukuyama, Fancis. 2001. Kemenangan Kapitalisme dan Demokrasi Liberal. Terjemahan. Yogyakarta: Qalam.

Gonggong, Anhar. 2001. Amandemen Konstitusi, Otonomi Daerah dan Federalisme, Solusi Untuk Masa' Depan. Yogyakarta: Media Pressindo. $\mathrm{H}^{\prime}$

Goul, Carol C... 1993. Demokrasi Ditinjau Kembali. Terjemahan. Yogyakartă: Tiara Wacana.

Handoyo, B.Hestu Cipto, Y.Thresianti. 2000. Dasar-Dasar Hukum Tata Negara Indonesia. Yogyakarta: Universitas Atma Jaya.
Huda, Ni'matul. 1999. Hukum Tata Negara Kajian Teoritis dan Yuridis Terhadap Konstitusi Indonesia. Yogyakarta: PSH Fakultas Hukum UII:

Kansil. 2002. Pancasila dan UndangUndang Dasar 1945. Jakarta: Pradnya Paramita.

Kristiarto, Yohanes SL. Dkk. 2001. Toeri Politik Modern. Jakarta: Penerbit Rajawali Pers.

Lev, 'Daniel S.. 1990. Hukum dan Politik di Indonesia. Terjemahan. Jakarta: LLP3ES. HIm. xxiv.

MD́, Moh.Mahfud. 1999. Hukum dan Pilarpilar Demokrasi. Yogyakäta: Gama Media.

2001. Politik Hukum di Indonesia. Jakarta: LP3ES.

Muis, A.. "Titian Jalan Demokrasi, Peranan Kebebasan Pers Úntuk Budaya "Komunikasi Politik." Kompas. 2000.

Shiraishi, Takasi. 2001. Menuju Demokrasi Politik Indonesia Dalam Persepektif Sejarah. Baskara: T.Wardaya (ed). Jakarta: Gramedia.

Silalahi, S.. 2001. Dasar-dasar Indonesia Merdeka versi Para Pendiri Negara. - Jakartạ:Gramedia Pusäka Utama.

Thaib, Dahlan. "Menuju Parlemen Bikameral (Studi Konstitusional perubahan Ketiga UUD 1945." Pidato Pengukuhan dalam jabatan Guru Besar Madya dalam Hukum Tata Negara. Disampaikan di depan Sidang Senat Terbuka Universitas Islam. Indonesia (UII) Yogyakarta pada tanggal 4 Mei 2002. 
Thalib, Muhammad, IIfan S.Awwas (ed). 1999:

Doktrin Zionisme dan Idiologi Pancasila Menguak Tabir Pemikiran Politik Founding Father RI. Yogyakarta: Widhah Press.

Wardaya, Baskara T., (ed). 2001. Menuju Demokrasi.Politik Indonesia Dalam Perspektif 'Sejarah. Jakarta: Gramedia:
Wibawa, Samodra. 1993. Demokrasi Ditinjau Kembali. Yogyakarta: Penerbit Tiara Wacana.

Kedaulatan Rakyat. 16 Mej 2002. Kompas. 11 Mei 2002.

\section{8}

